DOI: 10.17707/AgricultForest.62.3.15

\begin{abstract}
Mykola M.KHARYTONOV, Valentina T.PASHOVA, Maria O.BAGORKA, Vladymyr KOZECHKO
\end{abstract}

\title{
NUTRITION REGIMES OF ERODED LANDS IN THE NORTHERN STEPPE ZONE OF UKRAINE
}

\begin{abstract}
SUMMARY
The research of quantitative and qualitative composition of nitrogen, phosphorus, potassium, and soil enzymes activity in arable soils on the slopes and watersheds was performed. Soil erosion is considered as a result of a complex interaction of natural and agricultural factors. Among the main ones are the natural terrain, erosion resistance, vegetation soil-protective role, climatic and meteorological conditions that determine the rainfall, nature of soil freezing, the size and intensity of surface runoff snowmelt and rainwater. An intensity of erosion processes depends on the slopes characteristics, their steepness, shape, length, exposure. These factors different combinations give specificity of soil profile forming in slopes, generally similar, but not identical with soils of the neighbouring northward and southward latitudes. The experiments reported here compare soils from three types of landscapes: level soils (0-1\% slope) with no observable erosion (E0), mildly sloped soils (1-3\%) with mild erosion (E1, 0-10 $\mathrm{cm}$ topsoil loss), and moderately sloped soils (5-7\%) with moderate erosion (E2, up to $30 \mathrm{~cm}$ topsoil loss). The content of available forms nitrogen assimilation varies depending on the soil erosion degree. Urease activity decreases significantly with the depth, especially at E2 soils. The reduction of digestible phosphorus under the erosion impact was fixed two times in the slope of the southern exposure, in comparison with plain soil. The data obtained indicate the phosphatase activity decrease under the influence of flushing by $37-83 \%$. The decrease of potassium level in the slopes of the northern and the southern exposition reaches 1.5 and 2.5 times accordingly. A larger value of the ratio of nitrogen and phosphorus in the underlying eroded soils layers in the two test crops is associated with a much greater adaptive potential of peas comparative to the barley.
\end{abstract}

Keywords: soil, erosion, nutrients, uptake, biological activity.

\section{INTRODUCTION}

Ukrainian natural zones consist of three zones - forest, forest - steppe and steppe zone. Black soils take $76.8 \%$ or 11.9 mln.ha (Kravchenko, 2012). The Ukraine steppe can be divided in two subzones: northern and southern parts.

\footnotetext{
${ }^{1}$ Mykola M.Kharytonov, (corresponding author: nick-nick@mail.ru), Valentina T.Pashova, Maria O.Bagorka, Vladymyr Kozechko, Dnipropetrovsk State Agrarian and Economic University, Dnipropetrovsk, UKRAINE,

Notes: The authors declare that they have no conflicts of interest. Authorship Form signed online.
} 
Unsteady agriculture in the steppe zone of Ukraine is in most cases by rather changeable weather conditions relief and diversity of soil covering. Precipitation is less than $350 \mathrm{~mm}$ in dry years i.e. them dry steppe zone, in damp years more $550 \mathrm{~mm}$ live in forest-steppe zone (average perennial value $470 \mathrm{~mm}$ ). The relief makes worse the influence of the zonal climate, with redistribution climatic ecological recourses leads to draining of soil formation of soil erosion, deterioration of fertility of it (Kisic et al., 2016; Barovic et al, 2015). Agricultural zones differences are caused by horizon zones, vertical and similar ecological effect of soils of different granular composition (Kharytonov et al., 2009).

It is necessary to emphasize that black soils are prevalent in the steppe zone of Ukraine. Generally, black soils are not rich in available phosphorus. They have available $\mathrm{K}$ content ranging from medium to high. The reduction of fertilizer inputs leads to nutrition balance infringement and the development of degradation processes in the black soil (Shikula M.K., 2000). Erosion processes within steppe landscapes reach 40-50\%. Dnepropetrovsk region territory stretching for only $200 \mathrm{~km}$ from north to south and $270 \mathrm{~km}$ from east to west is characterized by the wide variety of ecological conditions that predetermine its division into separate agricultural zones and subzones (Kharytonov et al., 2009).

There are similar agricultural resources distribution connected with vertical zoning within separate elements of landscape. The educational farm "Samarsky" of DSAEU is known due to V.A.Kovda (1989) as farm with high level of agriculture including some elements of ecological farming: crop rotations with long and short - term grass and leguminous mixtures, forest land conservation, etc. Investigation of typical for center of Ukraine steppe the landscape has been done. Slopes with steepness 1,5 degree had weak-expressed erosion soils. Slopes with steepness 1,5-7 degree had washed off upper horizon of humus more than 2 times (Kharytonov et al., 2002).

In our research we set the following goal: to study the changes of nutrition regimes of arable lands (in plain and slopes of the northern and the southern exposure).

\section{MATERIAL AND METHODS}

Field observations were carried out at the ecological field station of the "Samarsky" farm located in the Dnipropetrovsk oblast in the northern part of the steppe zone of Ukraine. Soil for controlled experiments and laboratory analysis was sampled from the same location. The farm coordinates are: $48^{\circ} 30^{\prime}$ E lat. and $35^{\circ} 15^{\prime} \mathrm{N}$ long. The field station was used for many years as an area for intensive agricultural production and research. It is located far away from the city of Dnipropetrovsk $(25-30 \mathrm{~km})$ enough to avoid industrial pollution effect (Anisimova et al., 2009).The training farm "Samarsky" - agri-landscape scheme was highlighted to demonstrate the idea of the case study. Comparison of the received information regarding the crop yield with the landscape features offers the possibility to differentiate the agricultural resource potential of the area.The research field occupies an area of 14 hectares and it is crossed by three ravines. 
One of them is of $30 \mathrm{~m}$ depth with a slope of $>7^{\circ}$, the other two have the slopes up to $3^{\circ}$. Studies were performed on plain (full-height normal soil), on the northern exposition slope (low eroded soil), the slope of the southern exposure (middle level of erosion). Special attention was paid to the one of the three ravines: flat terrain, slopes of the southern and the northern exposure. Thus, the experiments reported here compare soils from three types of landscapes: level soils (0-1\% slope) with no observable erosion (E0), mildly sloped soils (1-3\%) with mild erosion (E1, 0-10 cm topsoil loss), and moderately sloped soils (5-7\%) with moderate erosion (E2, up to $30 \mathrm{~cm}$ topsoil loss).

Coincidentally, in the study area, the mildly sloped soils have the northern exposure, and the moderately sloped soils have the southern exposure. The soil type in the experimental area is referred to the central steppe chernozem in the FSU (former Soviet Union) system (Kharytonov, et al., 2004). Numerous soil characteristics were determined for each erosion severity and each $10 \mathrm{~cm}$ depth increment from bulk samples. Generally, duplicate determinations were made and averaged. The depth increments were assigned to general soil horizons, according to the Russian soil taxonomy system (Kovda, 1989). These are defined as follows (with correspondence to the Ukrainian soil taxonomy system (Kharytonov et al., 2004). Soil samples were taken every $10 \mathrm{~cm}$ to a depth of 100 $\mathrm{cm}$.

Up to 100 soil samples were taken in topsoil of ecological field.Percent of organic $\mathrm{N}(\mathrm{N} \%)$ and mineral $\mathrm{N}$ was determined by Kehldahl analysis of the bulk sample, including the organic matter. Nitrification energy was determined by the following procedure. A portion of a bulk sample for each erosion severity and depth was allocated to each of two $50 \mathrm{ml}$ Erlenmeyer flasks. $\mathrm{NO}_{3}$ concentration was determined for each flask immediately after the soil sampling, and again after 7 days incubation at $28 \mathrm{C}^{0}$ with daily addition of water just enough to keep the soil moisture for the period of experiment. $\mathrm{NO}_{3}$ concentration was determined using an ЭB-74 ion meter (Ion-meter factory, Gomel, Belorussia) and a nitrate selective ion electrode for $\mathrm{NO}_{3}$ (Ion Meter Factory, Tbilisi, Georgia). Using 4 equally-spaced concentrations of $\mathrm{KNO}_{3}$ from $10^{-2}$ to $10^{-5} \mathrm{M}$ (approximately equivalent to 0.78 to $780 \mathrm{mg} \mathrm{NO}_{3} / \mathrm{kg}$ of solution), a standard curve was prepared. For greater accuracy, this curve was divided into two segments $\left(10^{-2}\right.$ to $10^{-4} \mathrm{M}$ and $10^{-4}$ to $\left.10^{-5} \mathrm{M}\right)$. Humus concentration was determined by placing $0.1 \mathrm{~g}$ of soil in $10 \mathrm{ml}$ of $0.4 \mathrm{~N} \mathrm{~K}_{2} \mathrm{Cr}_{2} \mathrm{O}$ aqueous solution, followed by titration with salt of Moore $\left(\mathrm{FeSO}_{4}\left(\mathrm{NH}_{4}\right)_{2} \mathrm{SO}_{4}\right)$. The $\mathrm{C}: \mathrm{N}$ ratio was calculated from determinations of $\mathrm{N} \%$ (as above) and $\mathrm{C} \%$. C\% was determined as humus/1.72. Mobile $\mathrm{P}$ was determined by the colorimetric method of Denizhe, following offered by the Machigin extraction method. The method of Machigin is basically an extraction by a $1 \%$ solution of ammonia. Exchangeable $\mathrm{K}$ was evaluated by flame emission spectrophotometry after extraction by $1 \%\left(\mathrm{NH}_{4}\right)_{2}$ carbonate. $\mathrm{Ca}$ and $\mathrm{Mg}$ were determined by titration with EDTA. Urease was determined for each $10 \mathrm{~cm}$ up to the depth of $1 \mathrm{~m}$, phosphatase was determined for 3 pooled depths: 0-20, 20-40, and $40-60$. 
The pea and barley experiments involved two erosion levels (E1 and E2). It was made to establish the eroded soils effective fertility. Soil samples were taken every $10 \mathrm{~cm}$ to a depth of $1 \mathrm{~m}$ on each slope. The vessel volume is $5 \mathrm{~kg}$, repetition - 3. The experiments duration 90 days in greenhouse conditions under natural light and sufficient supply of water. $\mathrm{N}, \mathrm{P}_{2} \mathrm{O}_{5}$ and $\mathrm{K}_{2} \mathrm{O}$ uptake with pea and barley mass for each soil layer was accounted. The ratio for each nutrient between pea and barley was calculated as well. The nitrogen and phosphorus concentration in plant samples was estimated using Kjeldahl method. Total $\mathrm{P}$ concentrations of the applied residues were determined by sulfuric acid digestion (Thomas et al., 1967). Potassium was determined with flame photometry. Statistical analysis of each experiment was performed on Excel (2000), using the analysis package add-in.

\section{RESULTS AND DISCUSSION}

The different character of interaction of factors on the slopes and plains has led to the phenomenon of the soils biological activity diversity in arable landscapes. The ratio of rate $\mathrm{C} / \mathrm{N}$ changes at different depths (Fig 1).

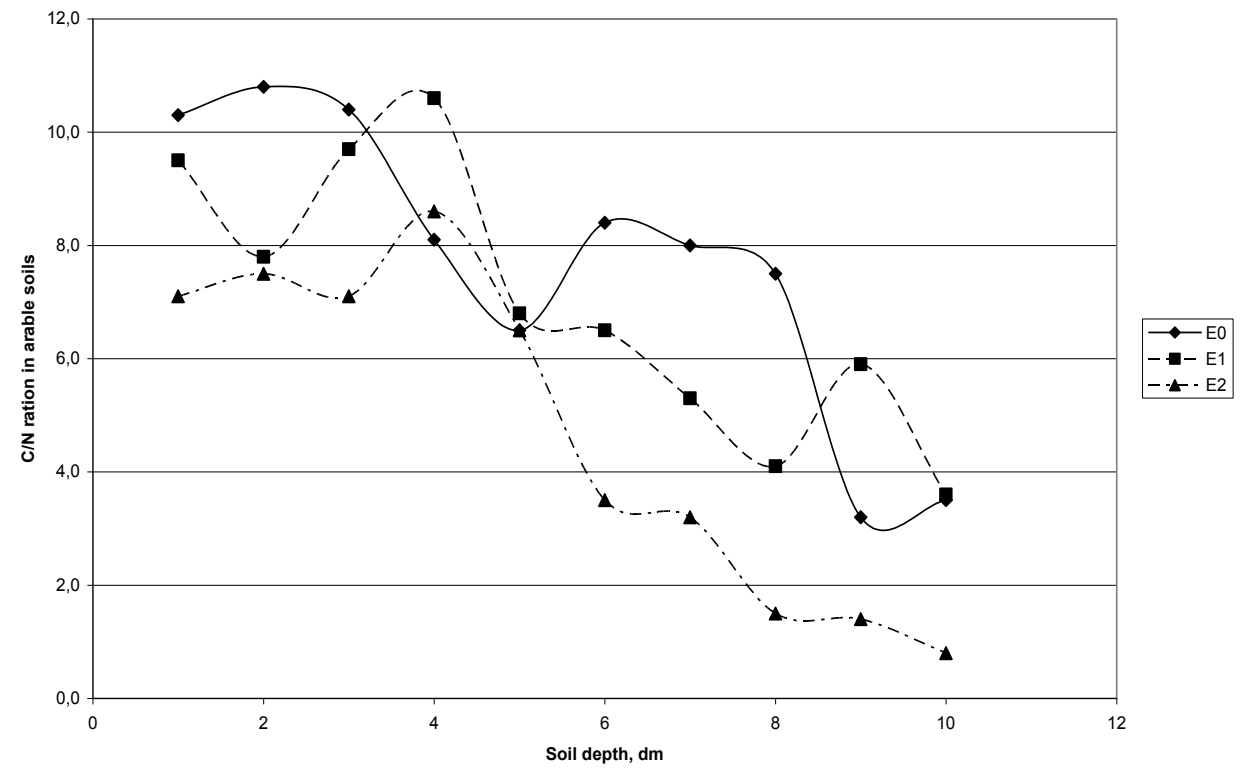

Figure 1. The $\mathrm{C}: \mathrm{N}$ ratio profile distribution in arable soils

The data analysis showed that the amount of humus decreases with the depth. The nitrogen content also decreases, but more slowly. This may explain the decrease in the $\mathrm{C}: \mathrm{N}$ ratio along the profile. The biological process of nitrification in the soil happens depending on several factors: soil moisture, temperature, aeration, and $\mathrm{pH}$ value. The nitrification process is the final step in 
the organic nitrogen transformation to available form for plants. The content of nitrogen assimilation available forms varies depending on the soil erosion degree. The data on arable soils nitrification energy are shown in the figure 2.

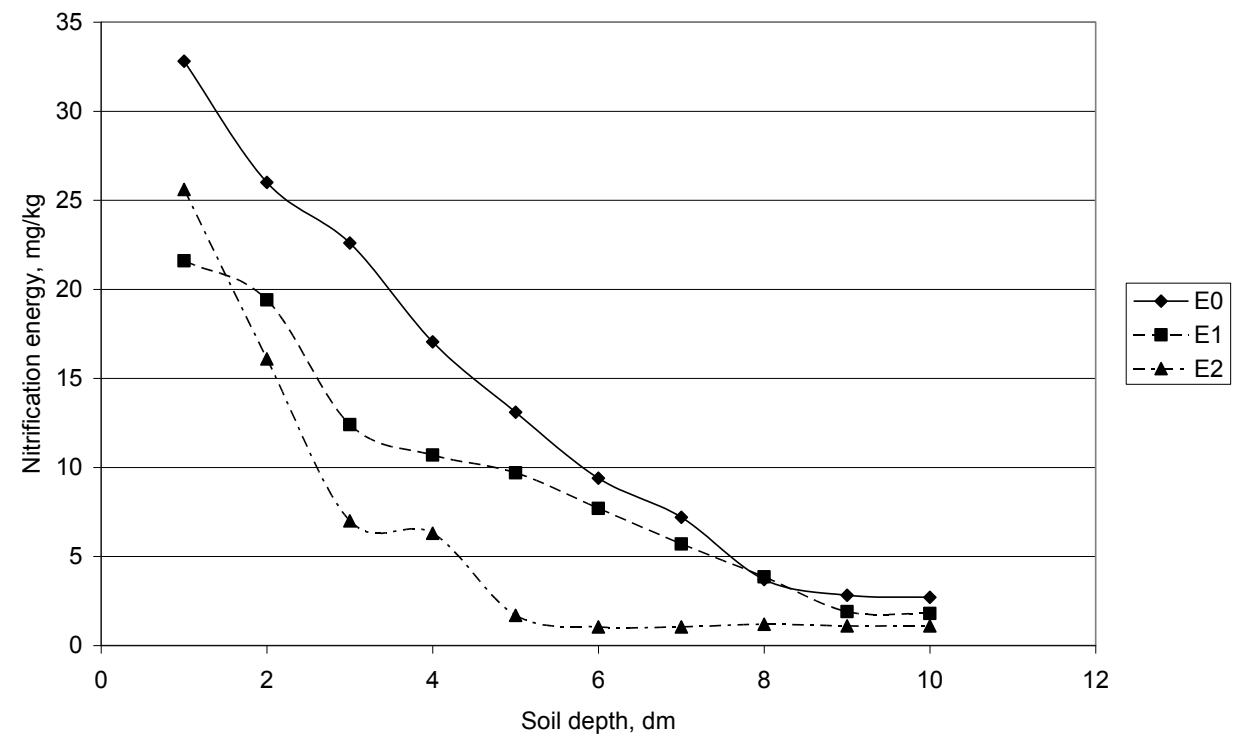

Figure 2. Nitrification energy profile distribution in arable soils

The greatest energy of nitrification $(27,1 \mathrm{mg} / \mathrm{kg})$ was in the E0 topsoil (0$30 \mathrm{~cm}$ ). Its value in the topsoil of slopes: $17.8 \mathrm{mg} / \mathrm{kg}$ (E1) and $16.2 \mathrm{mg} / \mathrm{kg}(\mathrm{E} 2)$. A common trend is the decrease of nitrate transformation rate with the depth.

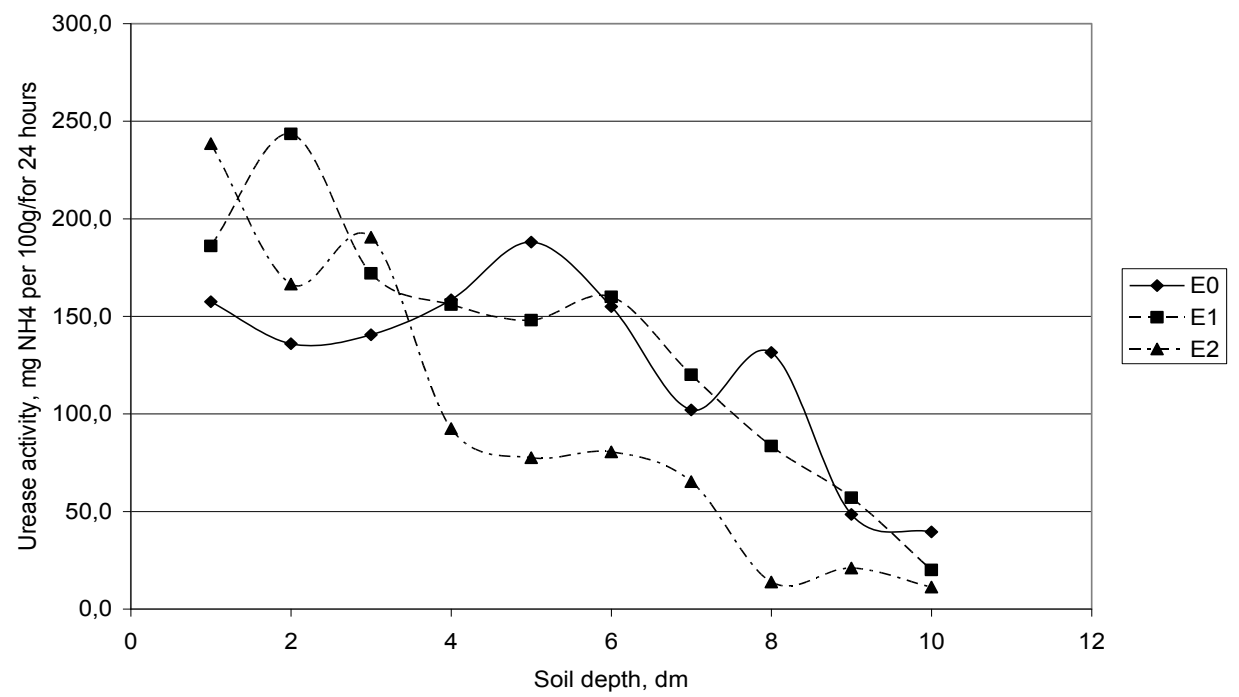

Figure 3. Urease activity in soil profiles (mg NH4 per $100 \mathrm{~g} /$ for 24 hours). 
As it is known such enzyme as urease has great influence on the soil nitrogen mobilization. The data portion on urease activity distribution in soil profiles are shown in the figure 3.

Data show urease activity increasing on the slopes of the northern and the southern exposure. However this pattern is observed in the only three topsoil layers: 0-10, 10-20 and 20-30 cm. Urease activity decreases significantly with the depth, especially at E2 soils. As it is known, phosphorus in the soil is accumulated in organic and mineral compounds. Mainly the phosphorus substances in soil are inaccessible compounds to plants (Kabata-Pendias, 1987). In this regard, the total phosphorus content in soil cannot give the trust information on the availability to the plants. Soil microorganisms and biochemical processes have a large impact on the mobility of phosphate in soil. The mobility of phosphorus stimulates the enzymatic system of the soil microorganisms. Biochemical processes contribute to the soluble and mobile phosphorus compounds accumulation. The lack of digestible phosphorus in eroded soils caused by the action of two factors: the washout and the amount of carbonates that reduce the mobility of phosphate (Shikula, 2000)]. A transitional horizon $(\mathrm{Hp}+\mathrm{Ph})$ is poor in the most mobile forms of phosphorus. This is due to the approximation to the surface of the rocks that have a low mobility of phosphates and significant phosphorus uptake crops yield. Both phosphate compounds mobilization and fixing in less mobile mineral and organic compounds occur in soil under the microbiological and biochemical processe $s$ influence. As a result of erosion processes in the humus horizon, rich in organic and mineral compounds, is washed away, and the surface are depleted with nutrients. The content of digestible phosphate is significantly reduced with the increasing of erosion degree. The digestible phosphate decreasing ranged from $165 \mathrm{mg} / \mathrm{kg}$ to $104 \mathrm{mg} / \mathrm{kg}$. Both total and recoverable reserves of phosphorus in eroded soils were determined in our studies. The phosphorus gross reserves can be considered as indicators of soil fertility as well. As usual, the nitrogen gross reserves predominate over phosphorus reserves in ordinary black mollisols. That is why, in favorable conditions (in the absence of factors that inhibit the nitrification process) the plants are often lack of phosphorus. A number of chemical and biological processes that influence the phosphates availability occur as a result of washout in addition to the mechanical soil particles removal. The ploughing is an additional factor that leads to carbonate uptake to the day surface. At that the mobile phosphorus content decreases. The data on content of digestible phosphate profile distribution in arable soils are showed in the figure 4. The reduction of digestible phosphorus under the erosion impact was fixed two times in the slope of the southern exposure, in comparison with plain soil. The content of digestible phosphate drop to a depth of $50 \mathrm{~cm}$ and further the indices are stabilized at a level of 7.3 to $8.5 \mathrm{mg} / \mathrm{kg}$.

Along with the content the stocks of digestible phosphorus are significantly reduced. An available phosphorus reserve is reduced by $30-50 \%$ in the layer of one meter thick under the erosion influence. The soluble 
phosphorus accumulation in soil occurs in the process of hard forms decomposition. These transformations occur under the enzymes influence. An enzymes activity in soils depends on the amount of organic matter and activity of microflora. The phosphatase activity distribution in soil profiles was observed (Fig.5).

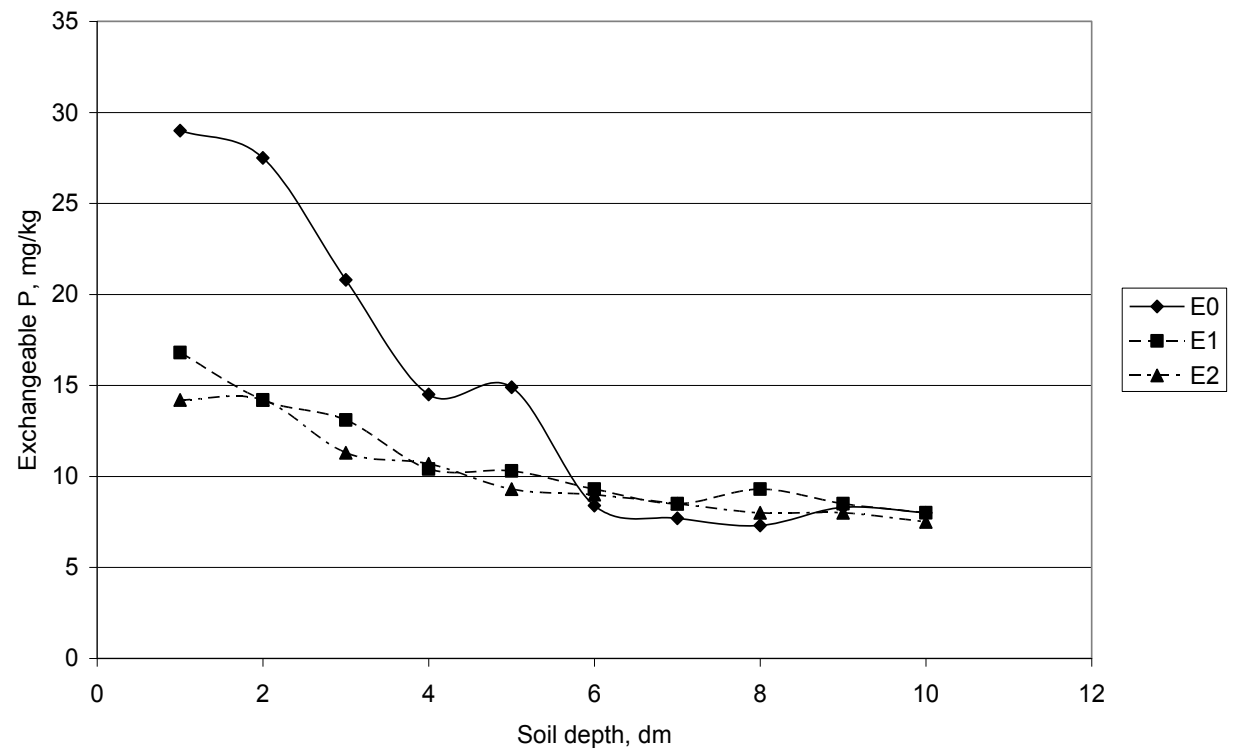

Figure 4. The digestible phosphate profile distribution in arable soils.

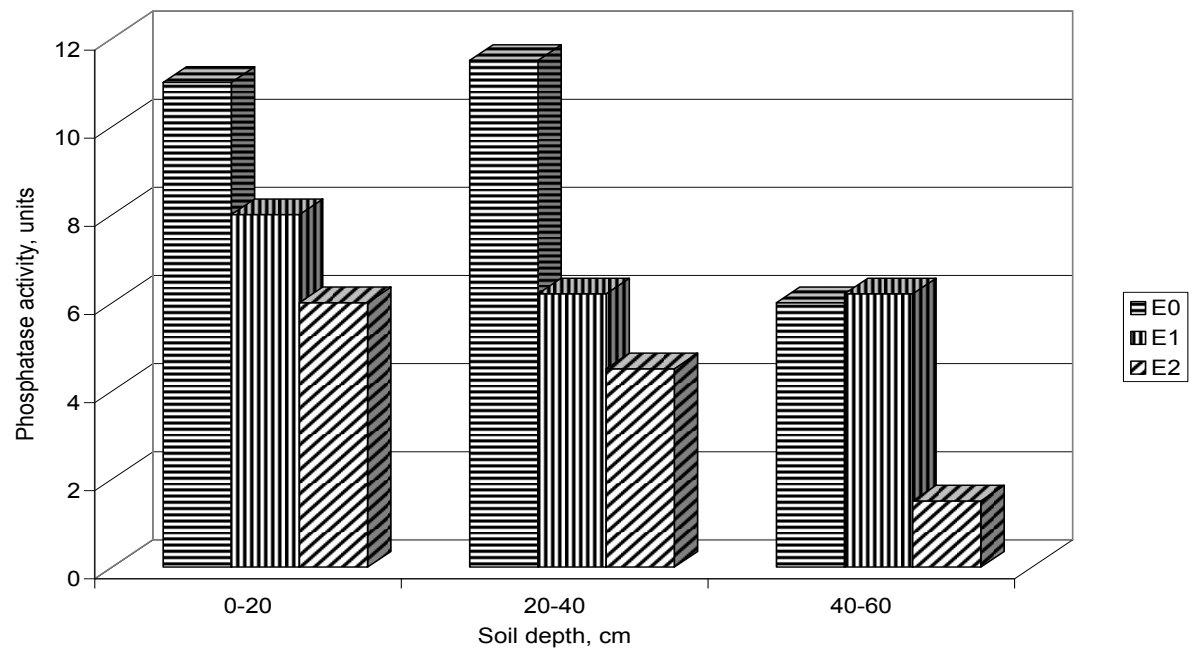

Figure 5. The phosphatase activity profile distribution in arable soils. 
The data obtained indicate the phosphatase activity decrease under the influence of flushing by $37-83 \%$. The phosphatase activity reduction reaches 4 times in E2 soil profile at a depth of $40-60 \mathrm{~cm}$ in comparison with E0.

This indicates a low mobilization of soil phosphates in eroded soils, especially at the exit of the transition horizon Hp to the surface.

Thus, the amplification of surface flushing is a risk factor for significant losses of phosphorus in the surface layer of eroded soils. The data on exchangeable potassium in ordinary black mollisols are shown in the figure 6 .

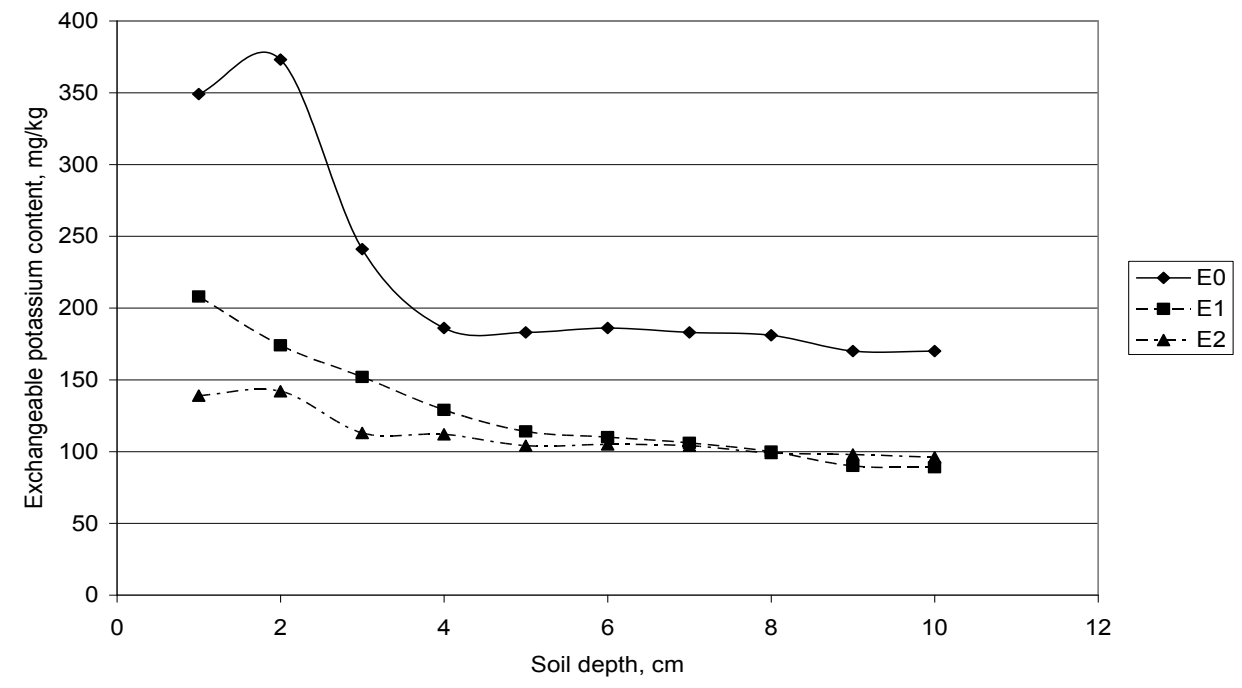

Figure 6. The exchangeable potassium profile distribution in arable soils.

The content of exchange potassium in the E0 soil is significant. The decrease of potassium level in the slopes of the northern and the southern exposition reaches 1.5 and 2.5 times accordingly.

Such a significant drop can be explained, firstly by flushing some part of the soil and leaching of potassium in aqueous solution.

The pea and barley were studied as biological indicators to estimate eroded soils fertility. A pea is largely due to nitrogen fixation removes the restrictions due to different nitrogen content in the soil genetic horizons. Barley is much more demanding of soil fertility.

Barley productivity is in direct proportion to the consumption of nutrients - nitrogen, phosphorus and potassium. The ratio for each nutrient to compare pea and barley adaptive potential for two types of eroded soils was calculated (Fig. 7 and 8).

The ratio index for pea and barley for nitrogen, $\mathrm{P}_{2} \mathrm{O}_{5}, \mathrm{~K}_{2} \mathrm{O}$ along E1 profile was 2.2-4.2; 1.3-4,5 and 1.2-2.4 times. At the same time the nitrogen and $\mathrm{P}_{2} \mathrm{O}_{5}$ distribution along E2 profile was 3.1-4.2 and 2.2-4.3. The similar uptake was fixed was potassium. 


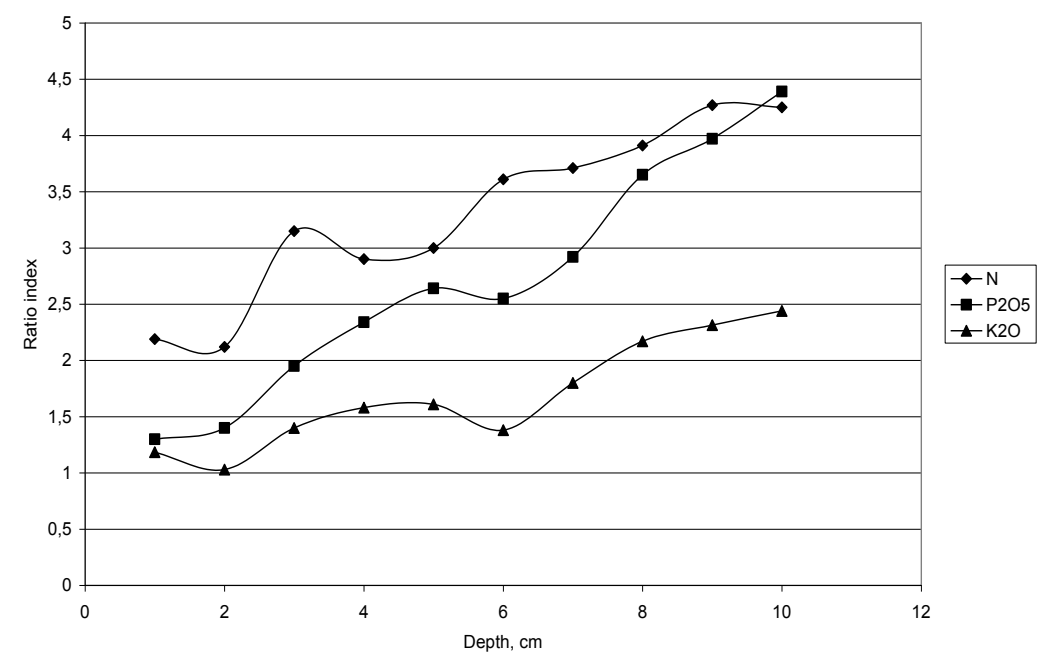

Figure 7. The pea/ barley ratio nutrition indexes profile distribution in E1 profile.

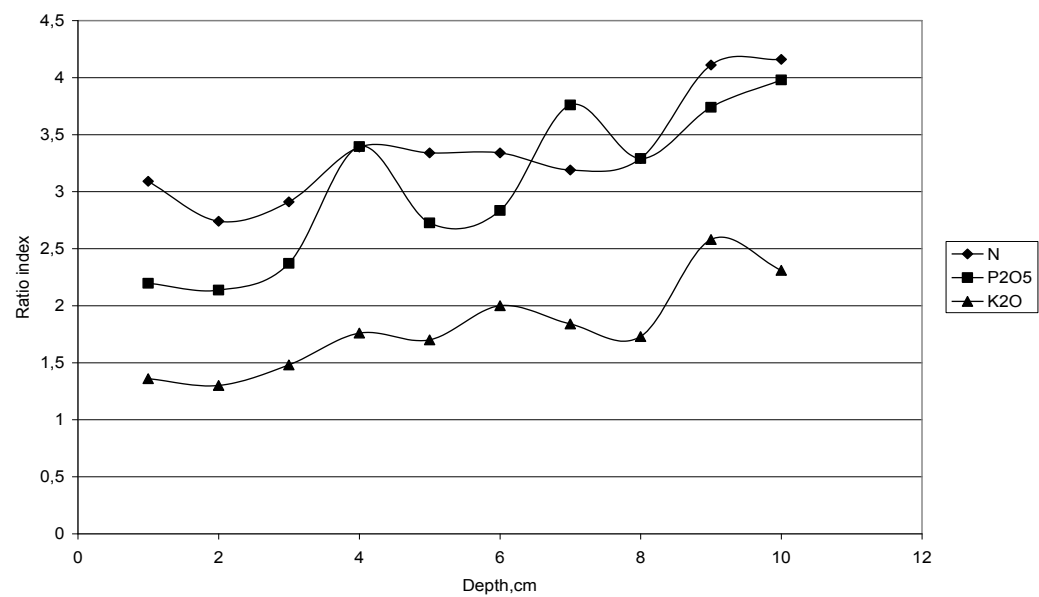

Figure 8 . The pea/ barley ratio nutrition indexes profile distribution in E2 profile.

\section{CONCLUSIONS}

The research of quantitative and qualitative composition of nitrogen, phosphorus, potassium, and soil enzymes activity in arable soils on the slopes and watersheds was performed. On the basis of it the dependence between the eroded soils fertility and environmental conditions was established. The slope soils are represented by the variety of watershed types of black mollisols. Essential changes in the content of available forms of nitrogen, phosphorus, potassium, and enzyme activity were established for eroded and non eroded soils.

The content of exchangeable phosphate and potassium is significantly reduced with the increasing of erosion degree. It was fixed different character of 
main nutrients uptake in two eroded soil types. The maximum consumption of peas of nitrogen, phosphorus and potassium was in the E1 soil profile in the layer $0-10$ and $10-20 \mathrm{~cm}$.

\section{ACKNOWLEDGEMENTS}

This study was supported with Ministry of Agrarian Policy and Food of Ukraine.

\section{REFERENCES}

Anisimova, LB, Gritsan, NP, Kharytonov, MM 2009. Land Distribution and Assessment in the Ukrainian Steppe within the Dnipropetrovsk Region. Regional Aspects of Climate -Terrestrial - Hydrologic Interactions in Non-boreal Eastern Europe, Springer: 201-210.

Barovic, G., Spalevic, V. (2015): Calculation of runoff and soil erosion intensity in the Rakljanska Rijeka Watershed, Polimlje, Montenegro. Agriculture and Forestry, 61(4): 109-115. doi:10.17707/agricultforest.61.4.11

Dokuchaev Soil Institute. 1965. Agrochemical methods of soil investigation. Ed. by USSR Academy of Science. Science Publishers, Moscow. 4th Ed. 436 p. (in Russian)

Kabata-Pendias, A, Pendias, H, 1987. Trace elements in soils and plants, 2nd ed.; Levis.Publ.Boca Raton.Fl. 365 p.

Kisic, I., Bogunovic, I., Birkás, M., Jurisic, A., Spalevic, V. (2016). The role of tillage and crops on a soil loss of an arable Stagnic Luvisol. Archives of Agronomy and Soil Science, 1-11. doi:10.1080/03650340.2016.1213815

Kharytonov, M., Bagorka, M., Gibson, P. 2004. Erosion effects in the central steppe chernozem soils of Ukraine. I.Soil Properties. Agricultura. Published by the University of Maribor, Faculty of Agriculture, Slovenia; Vol.3. № 1:12-18.

Kharytonov, MM, Mitsik, OO; Pashova, VT 2009. Development of Mathematic approaches to the Ecological Differentiation of Arable Land in the Dnipropetrovsk Area of Ukraine. Regional Aspects of Climate - Terrestrial Hydrologic Interactions in Non-boreal Eastern Europe, Springer:.221-232

Kovda, VA 1989. The problems of Earth biosphere and soil protection. Institute of Soil Science and Photosynthesis. Puschino, Russia:122-123 (in Russian)

Kravchenko, Y, Rogovska, N, Petrenko, L, Zhang, X, Song, C, Chen, Y, 2012. Quality and dynamics of soil organic matter in a typical Chernozem of Ukraine under different long-term tillage systems. In: Can. J. Soil Sci.;. 92: 429-438

Microsoft Corporation. 2000. EXCEL spreadsheet, Microsoft Office.

Shikula, MK,2000. Mechanism for self-regulation of fertility in Ukrainian chernozems. In: Soil Quality, Sustainable Agriculture and Environmental Security in Central and Eastern Europe NATO Science Series, Volume 69:259-266

Thomas, RL, Sheard, RW, Mayer, JR, 1967. Comparison of conventional and automated procedures for nitrogen, phosphorus and potassium analysis of plant material using a single digestion. Agron. J. 59: 240-243. 